\title{
Parameters of dynamic balance in the frontal and sagittal plane and their correlations with poor postures in children aged 10-12 from the Masłów district in Świętokrzyskie province
}

\section{Parametry równowagi dynamicznej w płaszczyźnie strzałkowej i czołowej oraz ich korelacje z wadami postawy u dzieci 10-12-letnich z gminy Masłów w województwie świętokrzyskim}

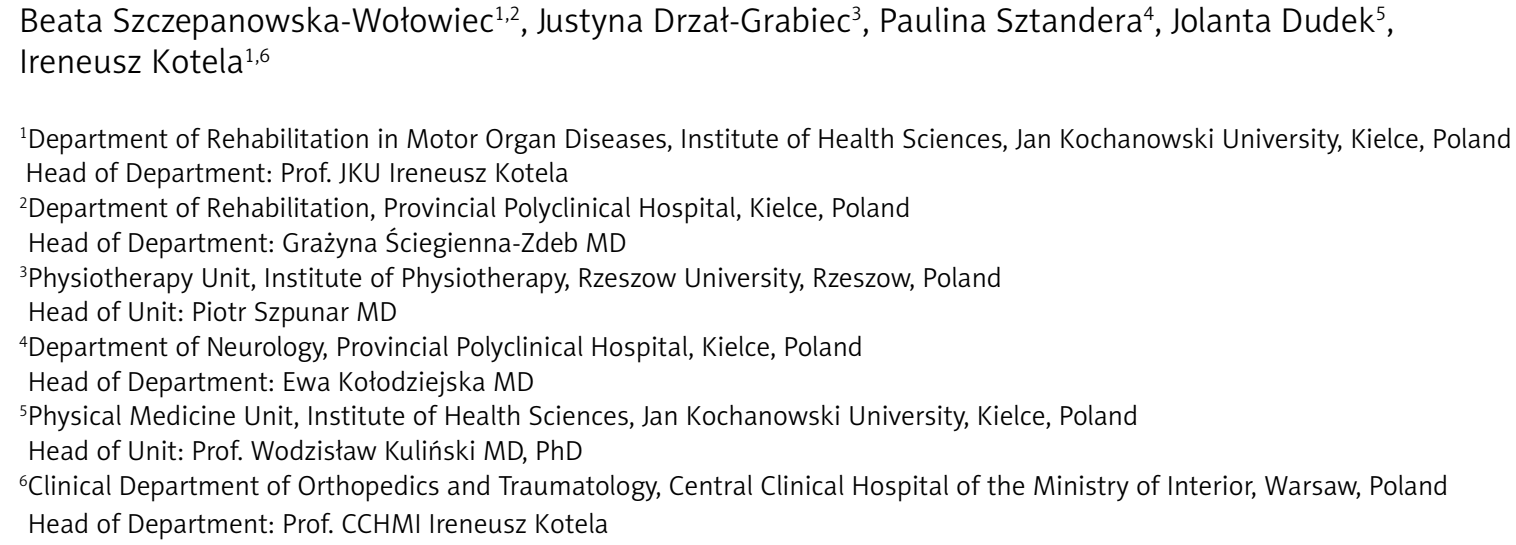

Key words: dynamic balance, Libra platform.

Słowa kluczowe: równowaga dynamiczna, platforma Libra.

\begin{abstract}
Introduction: Even postural asymmetry may provoke static and balance disorders.

Aim of the research: To define the level of dynamic balance among children aged 10-12 and find the correlations between poor postures.

Material and methods: This study was conducted among 176 children from Masłów district in Świętokrzyskie province. The Libra platform was used to examine the dynamic balance.

Results: Dynamic balance parameters from the sagittal and frontal plane show statistically significant differences between the control group and study groups.

Conclusions: The analysis of dynamic balance parameters from the sagittal and frontal plane confirms that the lowest values occur in the control group, higher in children with foot defect, and the highest in children with scoliotic posture.

\section{Streszczenie}

Wstęp: Niewielkie błędy postawy zaburzają statykę i równowagę tułowia.

Cel pracy: Określenie poziomu równowagi dynamicznej dzieci 10-12-letnich i jego korelacji z wadami postawy.

Materiał i metody: Badania przeprowadzono w grupie 176 dzieci z terenu gminy Masłów w województwie świętokrzyskim. Badania równowagi dynamicznej wykonano na platformie Libra.

Wyniki: W parametrach dotyczących równowagi dynamicznej w płaszczyznach czołowej i strzałkowej obserwuje się występowanie statystycznie znamiennych różnic pomiędzy grupą kontrolną a grupami badanymi.

Wnioski: Analiza parametrów równowagi dynamicznej w płaszczyźnie czołowej i strzałkowej potwierdza, że najmniejsze wartości występują w grupie kontrolnej, większe u dzieci z wadami stóp, a największe w grupie dzieci z postawą skoliotyczną.
\end{abstract}




\section{Introduction}

A lot of scientific disciplines are interested in studying the notion of balance. Balance is defined as a certain condition of the postural system which is ensured by the nervous system due to reflexive tension of particular muscle groups known as postural or antigravity muscles. Researchers distinguish two types of balance, namely static balance, defined as the ability to maintain a balanced position, and dynamic balance, which consists in maintaining or regaining a balanced position while performing or directly after finishing a physical activity. Static and dynamic balance are considered within two frames: sagittal and frontal [1-4].

The main purpose of the balance system is to maintain the centre of gravity in a balanced position both at rest and during exercise.

A proper body posture depends on appropriate processing and interpretation of information provided by proprioceptive receptors, receptors of balance organs and sight sense. A child can often adopt an appropriate posture by correcting asymmetries and scoliosis, but even such insignificant adjustments influence the disorder of body statics and global body posture.

A problem noticed among children with postural defects is the deficit of balance maintenance.

\section{Aim of the research}

The purpose of this study is to assess the parameters of dynamic balance in the frontal and sagittal plane among children aged 10-12 with postural abnormities of the trunk and feet.

\section{Material and methods}

The study population consisted of 176 children aged 10-12 years from the Masłów district. The research was conducted in 2009 and in 2010. After being informed about the programme of the research, children's guardians or parents gave their written consent to participation in the study. All students participating in the study were divided into three age groups: 10, 11 and 12 years old (Table 1).

The evaluation of posture was conducted using the photogrammetry method that is based on the projection moiré phenomenon. Thus, a precise assessment of the postures of children in sagittal, frontal and transverse planes was possible [5]. The foot structure was assessed as well. Flat foot (slightly, moderately and severely), flaccid flat foot, claw foot and high arched foot (slightly and severely) were distinguished. After the study, the children received their results of photogrammetric analysis of posture which were later used to divide them into appropriate groups.

After the assessment of body posture, the children were divided into the following groups: group I - children with scoliosis up to $5^{\circ}$, group II - children with feet disorders - flaccid flat foot, and control group.

Children with scoliosis above $5^{\circ}$, severe chest disorders and those being treated in specialist counselling centres were not assigned to the study groups.

Table 2 presents age division in particular groups and Figure 1 shows the gender division.

Table 1. Number and age of respondents ( $n$ - number of respondents)

\begin{tabular}{|c|c|c|c|c|c|c|c|c|}
\hline \multirow[t]{3}{*}{ Gender } & \multicolumn{6}{|c|}{ Age [years] } & \multirow{2}{*}{\multicolumn{2}{|c|}{ Total }} \\
\hline & \multicolumn{2}{|c|}{10} & \multicolumn{2}{|c|}{11} & \multicolumn{2}{|c|}{12} & & \\
\hline & $n$ & $\%$ & $n$ & $\%$ & $n$ & $\%$ & $n$ & $\%$ \\
\hline Girls & 30 & 17.05 & 37 & 21.02 & 28 & 15.91 & 95 & 53.98 \\
\hline Boys & 28 & 15.91 & 33 & 18.75 & 20 & 11.36 & 81 & 46.02 \\
\hline Total & 58 & 32.96 & 70 & 39.77 & 48 & 27.27 & 176 & 100 \\
\hline
\end{tabular}

Table 2. Age division in particular groups

\begin{tabular}{|c|c|c|c|c|c|c|c|}
\hline \multirow[t]{3}{*}{ Group } & \multirow{3}{*}{$N$} & \multicolumn{6}{|c|}{ Age [years] } \\
\hline & & \multicolumn{2}{|c|}{10} & \multicolumn{2}{|c|}{11} & \multicolumn{2}{|c|}{12} \\
\hline & & $n$ & $\%$ & $n$ & $\%$ & $n$ & $\%$ \\
\hline I & 62 & 25 & 40.32 & 18 & 29.03 & 19 & 30.65 \\
\hline II & 65 & 18 & 27.69 & 27 & 41.54 & 20 & 30.77 \\
\hline Control & 49 & 15 & 30.61 & 25 & 51.02 & 9 & 18.37 \\
\hline
\end{tabular}




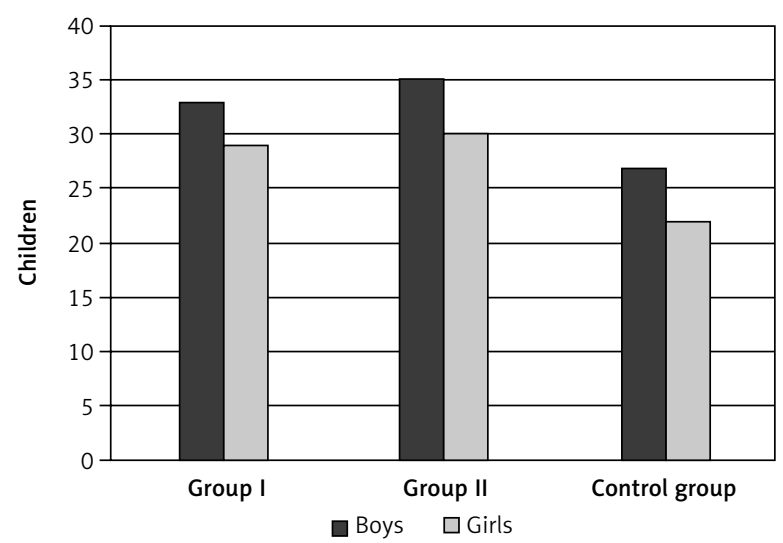

Figure 1. Gender division of respondents

Group I consists of 33 girls (53.23\%) and 29 boys (46.77), group II of 35 girls (53.85\%) and 30 boys (46.15\%). Control group: 27 girls (55.10\%), 22 boys (44.90\%) (Figure 1).

In order to examine the dynamic balance, balance training and evaluation, the Libra platform manufactured by the Italian company Easy Tech was employed (Figure 2). The position for conducting the study was composed of a platform with USB connector and a notebook attached thereto. The platform is provided with three different oscillating radiuses $(10 \mathrm{~cm}, 24 \mathrm{~cm}$ and $40 \mathrm{~cm})$. The software enables the user to use different analytical curves: straight line, sinusoid, square or triangular wave.

The model line is a straight line (deviation of $\pm 5^{\circ}$ from the model line). The curvature of balance of $40 \mathrm{~cm}$ with the sixth level of difficulty was employed. The instrument specifies the level of dynamic stability in unnatural conditions and provides the user with a surface included between the model line (straight line) and the real course of motion (total surface).

With the device properly set, the measurements were performed in the frontal and sagittal plane. Each measurement lasted one minute and was preceded by a 30-second warm-up. The study was conducted while standing straight in a natural posture, with feet aligned and eyes open. The data collected were stored on a hard drive using the program dedicated to the Libra platform.

In the sagittal and frontal plane the following parameters were assessed:

The total surface is the line of the course of motion on two sides of the model line that was reached by the examined person (sagittal plane - front, back; frontal plane - left and right side).

The external surface (widened surface) is the surface of the line of the course of motion that sticks out of a specified level of difficulty (sagittal plane - front, back; frontal plane - left and right side).

The external time (widened time) is the sum of time spent by the examined person beyond a particu-

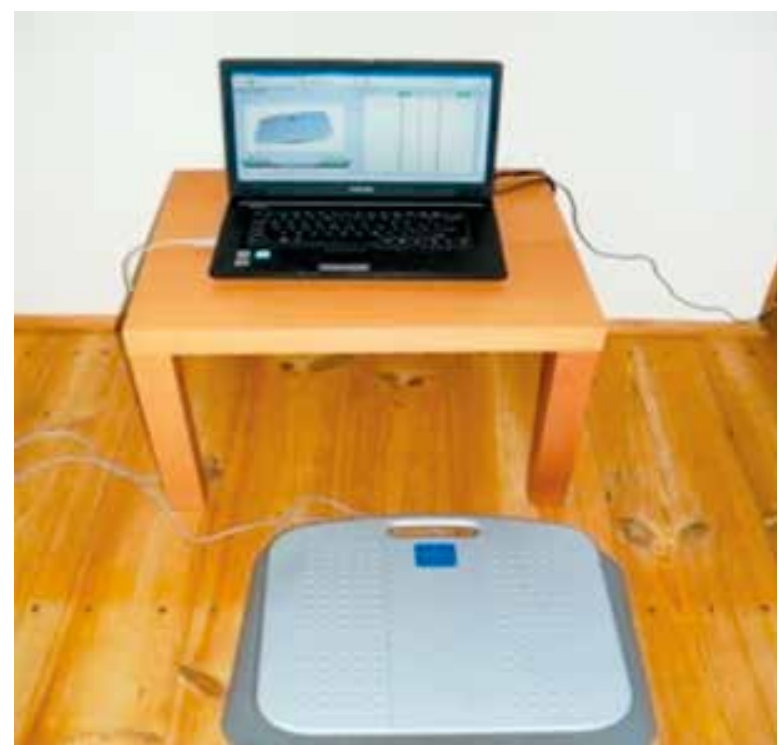

Figure 2. Balanced Libra platform made by Italian company Easy Tech. Source: own materials

lar level of difficulty (sagittal plane - front, back; frontal plane - left and right side).

The time of return (time of response) is the longest period of time beyond a particular surface (sagittal plane - front, back; frontal plane - left and right side).

The global assessment includes weighted mean (0-100) of eight parameters that were taken into consideration while assessing particular exercises, where 0 designates the best result, and 100 the worst.

\section{Results}

The results of the balance research conducted on the platform indicated the purpose of studies that were carried out because statistically significant differences between the control group and the groups that included children with postural defects and between studied groups themselves were present both in the frontal and sagittal plane.

The dynamic balance in the frontal plane in children from group I $(p<0.001)$ differs significantly from the control group in respect of all parameters analyzed. Those parameters are higher among children with scoliosis than among children from the control group.

The dynamic balance in the frontal plane in children with feet defects from group II $(p<0.001)$ differs significantly from the control group in respect of all parameters analyzed. Those parameters are higher among children with feet defects than among children from the control group.

It is observed that all parameters that were analyzed in the frontal plane adopt the smallest values in 
Table 3. Dynamic balance parameters - frontal plane

\begin{tabular}{|c|c|c|c|c|c|c|c|c|c|}
\hline Frontal plane & Group & $N$ & $x$ & $S$ & Minimum & Maximum & $\begin{array}{c}\text { Control } \\
- \text { II }\end{array}$ & Control - I & I - II \\
\hline \multirow{3}{*}{$\begin{array}{l}\text { Average total } \\
\text { surface }\end{array}$} & I & 62 & 95.73 & 37.24 & 37.50 & 209.10 & \multirow{3}{*}{$p<0.001$} & \multirow{3}{*}{$p<0.001$} & \multirow{3}{*}{$p=0.029$} \\
\hline & II & 65 & 83.69 & 22.81 & 47.25 & 138.35 & & & \\
\hline & Control & 49 & 43.68 & 9.58 & 20.95 & 79.40 & & & \\
\hline \multirow{3}{*}{$\begin{array}{l}\text { Average } \\
\text { external } \\
\text { surface }\end{array}$} & I & 62 & 13.64 & 17.82 & 0.05 & 74.25 & \multirow{3}{*}{$p<0.001$} & \multirow{3}{*}{$p<0.001$} & \multirow{3}{*}{$p=0.139$} \\
\hline & II & 65 & 9.87 & 9.72 & 0.30 & 37.35 & & & \\
\hline & Control & 49 & 0.90 & 1.67 & 0.00 & 8.70 & & & \\
\hline \multirow{3}{*}{$\begin{array}{l}\text { Average } \\
\text { external time }\end{array}$} & I & 62 & 5.47 & 4.74 & 0.10 & 22.20 & \multirow{3}{*}{$p<0.001$} & \multirow{3}{*}{$p<0.001$} & \multirow{3}{*}{$p=0.058$} \\
\hline & II & 65 & 4.14 & 2.88 & 0.50 & 11.40 & & & \\
\hline & Control & 49 & 0.63 & 0.76 & 0.00 & 4.10 & & & \\
\hline \multirow{3}{*}{$\begin{array}{l}\text { Average return } \\
\text { time }\end{array}$} & I & 62 & 1.29 & 1.14 & 0.10 & 5.95 & \multirow{3}{*}{$p<0.001$} & \multirow{3}{*}{$p<0.001$} & \multirow{3}{*}{$p=0.226$} \\
\hline & II & 65 & 1.09 & 0.66 & 0.30 & 3.10 & & & \\
\hline & Control & 49 & 0.32 & 0.30 & 0.00 & 1.70 & & & \\
\hline \multirow{3}{*}{$\begin{array}{l}\text { Average global } \\
\text { assessment }\end{array}$} & I & 62 & 10.75 & 6.24 & 3.00 & 32.10 & \multirow{3}{*}{$p<0.001$} & \multirow{3}{*}{$p<0.001$} & \multirow{3}{*}{$p=0.080$} \\
\hline & II & 65 & 9.12 & 3.98 & 4.50 & 21.20 & & & \\
\hline & Control & 49 & 3.59 & 1.15 & 1.50 & 8.80 & & & \\
\hline
\end{tabular}

Table 4. Dynamic balance parameters - sagittal plane

\begin{tabular}{|c|c|c|c|c|c|c|c|c|c|}
\hline Sagittal plane & Group & $N$ & $x$ & $S$ & Minimum & Maximum & $\begin{array}{c}\text { Control } \\
- \text { II }\end{array}$ & Control - I & $I-I I$ \\
\hline \multirow{3}{*}{$\begin{array}{l}\text { Average total } \\
\text { surface }\end{array}$} & 1 & 62 & 102.40 & 28.41 & 55.15 & 195.35 & \multirow{3}{*}{$p<0.001$} & \multirow{3}{*}{$p<0.001$} & \multirow{3}{*}{$p=0.001$} \\
\hline & II & 65 & 88.06 & 19.87 & 50.95 & 146.40 & & & \\
\hline & Control & 49 & 57.29 & 14.44 & 33.25 & 83.55 & & & \\
\hline \multirow{3}{*}{$\begin{array}{l}\text { Average external } \\
\text { surface }\end{array}$} & I & 62 & 17.66 & 11.55 & 2.45 & 61.80 & \multirow{3}{*}{$p<0.001$} & \multirow{3}{*}{$p<0.001$} & \multirow{3}{*}{$p=0.002$} \\
\hline & II & 65 & 12.19 & 8.16 & 1.60 & 29.30 & & & \\
\hline & Control & 49 & 3.58 & 3.35 & 0.10 & 11.45 & & & \\
\hline \multirow{3}{*}{$\begin{array}{l}\text { Average external } \\
\text { time }\end{array}$} & 1 & 62 & 6.60 & 2.91 & 1.45 & 16.20 & \multirow{3}{*}{$p<0.001$} & \multirow{3}{*}{$p<0.001$} & \multirow{3}{*}{$p<0.001$} \\
\hline & II & 65 & 4.86 & 2.43 & 1.05 & 10.50 & & & \\
\hline & Control & 49 & 1.87 & 1.41 & 0.20 & 5.20 & & & \\
\hline \multirow{3}{*}{$\begin{array}{l}\text { Average return } \\
\text { time }\end{array}$} & I & 62 & 1.53 & 0.74 & 0.50 & 4.55 & \multirow{3}{*}{$p<0.001$} & \multirow{3}{*}{$p<0.001$} & \multirow{3}{*}{$p=0.053$} \\
\hline & ॥ & 65 & 1.31 & 0.55 & 0.40 & 3.25 & & & \\
\hline & Control & 49 & 0.69 & 0.33 & 0.20 & 1.55 & & & \\
\hline \multirow{3}{*}{$\begin{array}{l}\text { Average global } \\
\text { assessment }\end{array}$} & 1 & 62 & 12.17 & 4.02 & 5.20 & 24.80 & \multirow{3}{*}{$p<0.001$} & \multirow{3}{*}{$p<0.001$} & \multirow{3}{*}{$p<0.001$} \\
\hline & ॥ & 65 & 9.82 & 2.88 & 4.50 & 16.60 & & & \\
\hline & Control & 49 & 5.47 & 1.96 & 2.70 & 9.10 & & & \\
\hline
\end{tabular}


the control group, higher in group II, and the highest in group I (Table 3).

The dynamic balance in the sagittal plane in children from group I $(p<0.001)$ differs significantly from the control group in respect of all parameters analyzed. Those parameters are higher among children with scoliosis than among children from the control group.

The dynamic balance in the sagittal plane in children from group II $(p<0.001)$ differs significantly from the control group in respect of all parameters analyzed. Those parameters are higher among children with feet defects than among children from the control group.

It is observed that all parameters that were analyzed in the sagittal plane adopt the smallest values in the control group, higher in group II, and the highest in group I (Table 4).

\section{Discussion}

Adopting and maintaining a proper body posture determines a properly shaped bone-ligament system, a well-developed and efficient muscular system and an efficient nervous system which is responsible for regulating the body posture, including balance. Maintaining the body in a straight line is a result of very precise coordination of muscular and nervous systems. Due to the coordination of balance organs, sight, proprioceptive receptors and the central nervous system, regulation of body posture in appropriate conditions constitutes a dynamic process which comes naturally. Any disturbances may result in deterioration of body statics [5-7].

Depending on the level of influence of external environmental stimuli, overall health condition and fixed motor habits, a proper or faulty body posture is shaped. The most common occurrences are defects in spine alignment and arrangement of particular parts of movement organs. Even small changes in the structure or function of one element results in distant changes in the movement organ and thus influence faulty posture which may later transform into postural defects and have a negative morphological component $[8,9]$.

The ability to maintain balance is disturbed if any part of the system does not operate properly. Disturbances of the body control system in static conditions may be compensated, whereas such compensation in dynamic conditions may be delayed or insufficient [10]. It is essential especially in scoliotic postures when any disorder of the body statics in static conditions may be compensated, whereas in dynamic conditions the lack of compensation is noticeable.

The literature contains a lot of studies which support the theory that children with scoliosis possess worse abilities to keep balance and stability [11].
It has been noticed as well in our own studies that the deficit of ability to keep balance constitutes a problem present among children with postural defects. Own studies confirm that the bigger the postural defect is, the more severe are the disorders with maintaining dynamic balance. Similar results were obtained in studies conducted by Ostrowska et al. [4], Janiszewska et al. [12], Chamera-Bilińska et al. [13], Hertel et al. [14], and Wiernicka et al. [15].

Worse results of the ability to keep dynamic balance among children with postural defects are signals for therapists to introduce actions to improve the stability into therapeutic practice.

\section{Conclusions}

The analysis of the parameters of dynamic balance in the frontal and sagittal plane confirms the fact that the lowest values appear in the control group, higher among children with feet defects, and the highest in the group of children with scoliotic posture. In the sagittal and frontal plane among children with scoliotic posture, the parameter of total area reaches the highest values. In the sagittal and frontal plane among children with feet defects, the parameter of total area reaches the highest values as well. Statistically significant differences between the study groups and the control group appear.

\section{References}

1. Baczkowicz D, Szczegielniak J, Proszkowiec M. Zależności między stabilnością postawy, funkcją chodu a upadkami osób w wieku podeszłym - doniesienia wstępne. Ortopedia, Traumatologia, Rehabilitacja 2008; 10: 473-480.

2. Cachupe WJ, Shifflett B, Kahanov L, Wughalter EH. Reliability of biodex balance system measures. Measurement in physical education and exercise science 2001; 5: 97-108.

3. Juras G. Koordynacyjne uwarunkowania procesu uczenia się utrzymywania równowagi ciała. AWF, Katowice 2003.

4. Ostrowska B, Rożek-Piechura K, Skolimowski T. Odzyskiwanie dynamicznej równowagi po zewnętrznych zaburzeniach postawy u dzieci z idiopatyczną skoliozą. Ortopedia, Traumatologia, Rehabilitacja 2006; 3: 300-307.

5. Grabara M, Pstrągowska D. Ocena postawy ciała dziewcząt i chłopców w świetle wskaźnika względnej masy ciała. Polish Journal of Sports Medicine 2008; 24: 231-239.

6. Kutzner-Kozińska M. Proces korygowania wad postawy. AWF, Warszawa 2004

7. Szczygieł A, Janusz A, Marchewka A. Ocena wybranych parametrów postawy ciała dzieci i młodzieży przy użyciu nowoczesnej techniki diagnostyczno-pomiarowej w aspekcie terapeutycznym. Medycyna Sportowa 2001; 17: 419-423.

8. Kowalczyk A, Brzęk A, Nowotny-Czupryna O et al. Niektóre odległe skolioz rozpoznanych w wieku szkolnym. Fizjoterapia Polska 2008; 4: 418-424.

9. Zemkova E, Viitasalo J, Hannola $\mathrm{H}$ et al. The effect of maximal exerciseon static and dynamic balance in athletes and non-athletes. Medicina Sportiva 2007; 11: 70-77. 
10. Browne J, O Hare N. Review of the different methods for assessing standing balance. Physiotherapy 2001; 87: 489-495.

11. Wilczyński J. Boczne skrzywienie kręgosłupa a długość ścieżki posturogramu u dziewcząt i chłopców w wieku 12-15 lat. Kwartalnik Ortopedyczny 2012; 1: 126-134.

12. Janiszewska R, Tuzinek S, Nowak $S$ et al. Nieprawidłowości postawy ciała u dzieci 6-12-letnich - uczniów szkół podstawowych z Radomia. Probl Hig Epidemiol 2009; 3: 342-346.

13. Chamera-Bilińska D, Zawdzka D, Sobera M et al. Stabilność ciała w pozycji stojącej dzieci z bocznym idiopatycznym skrzywieniem kręgosłupa. Annales Universitatis Mariae Curie-Składowska Lublin 2005; 16: 218-221.

14. Hertel J, Gay MR, Denegar CR. Differences in postural control during single-leg stance among healthy individuals with different foot types. J Athl Train 2002; 37: 129-132.

15. Wiernicka M, Kaczmarek D, Kamińska E et al. Kontrola postawy ciała w zależności od wydolności stóp u dzieci z bocznym skrzywieniem kręgosłupa. Fizjoterapia Polska 2008; 3: 299-309.

\section{Address for correspondence:}

Beata Szczepanowska-Wołowiec MD

Institute of Health Sciences

Jan Kochanowski University

al. IX Wieków Kielc 19, 25-317 Kielce, Poland

Phone: +48 604144751

E-mail: beatawolowiec@op.pl 